\title{
Genetic Differentiation Caused by Chromium Treatment in Leersia hexandra Swartz Revealed by RAPD Analysis
}

\author{
X. W. Cai*, Y. Shao, Z. M. Lin \\ College of Earth Science, Guilin University of Technology, Guilin City, China \\ Email: ${ }^{*}$ monkeycxw@tom.com
}

Received 26 August 2014; revised 18 September 2014; accepted 25 September 2014

Copyright (C) 2014 by authors and Scientific Research Publishing Inc.

This work is licensed under the Creative Commons Attribution International License (CC BY).

http://creativecommons.org/licenses/by/4.0/

(c) $\underset{\mathrm{EY}}{\mathrm{i}}$ Open Access

\section{Abstract}

Randomly amplified polymorphic DNA (RAPD) technique was applied to assess the genetic variations and phylogenetic relationships in genetic differentiation within 4 Chromium-treatment Leersia hexandra. The fresh leaves of Leersia hexandra cultivated on the condition of chrome pollution and exogenous organic acids were used as experimental material. The genomic DNA of Leersia hexandra was extracted by using CTAB method. The results showed that different samples of Leersia hexandra exhibited DNA polymorphism when using the random primer S43, S51and S55 as the primers in the RAPD reaction. One specific DNA band about 1000 bp was found in the sample which treated with $10 \mathrm{mmol} / \mathrm{L}$ concentration EDTA when used the S43 primer to RAPD. The obvious differences between different EDTA-treatment levels suggest that EDTA has certain effects on enrichment to heavy metals of Leersia hexandra, it will be more favored to Leersia hexandra accumulation of chromium when EDTA concentration increased.

\section{Keywords}

Chromium Treatment, Genetic Differentiation, Randomly Amplified Polymorphic DNA (RAPD), Leersia hexandra Swartz

\section{Introduction}

Leersia hexandra Swartz, a perennial marshy plant, has been reported to be a Cr-accumulating plant with high tolerance to Cr. Under nutrient solution culture, it did not show any obvious symptoms of $\mathrm{Cr}$ toxicity when $\mathrm{Cr}$ concentrations in the leaves reached $5608 \mathrm{mg} \cdot \mathrm{kg}^{-1}$ dry weight [1]

"Corresponding author.

How to cite this paper: Cai, X.W., Shao, Y. and Lin, Z.M. (2014) Genetic Differentiation Caused by Chromium Treatment in Leersia hexandra Swartz Revealed by RAPD Analysis. Open Journal of Soil Science, 4, 366-373.

http://dx.doi.org/10.4236/ojss.2014.410037 
Previous and continuous researches show that environmental factors have a significant impact on the plants [2]. Excessive $\mathrm{Cr}$ in soil has negative impact on plant growth. At the same time, it can also accumulate in plants by roots, and enter human and animal bodies and harm them through the food chain [3].

Random Amplified Polymorphic DNA (RAPD) is a kind of molecular marker based on PCR. It uses 10 bp random primers amplifying the different DNA fragments in genome to show the polymorphism [4] [5]. One RAPD amplification is actually a simple PCR reaction, and it suits for a large number of samples for rapid analysis. The required DNA template is very small amounts, generally an amplification of only 10 ng to 50 ng DNA [6]. RAPD was used to determine genetic variability of ten populations of alfalfa [7] and the relationships between RAPD markers and 22 quantitative traits of caraway (Carum carvi L.) were analyzed [8]. The RAPDPCR method was used to describe the pattern of DNA band variation in the samples influenced by the environmental pollution, to describe the level of pollution in an area contaminated with smoke and waste from an ironsteel factory, and to reveal the level of potential [9].

At present, there are not molecular biology reports on heavy metal chromium enrichment of $L$. hexandra, and little molecular ecology study on plants to heavy metal pollutants under the long -term effect. Reports on using RAPD to analyze heavy metal pollution on plant population genetic diversity are increasing recently, Li et al. (2007) used RAPD to analyze genetic diversity and genetic differentiation of Dicranopteris dichotoma populations and lead-zinc mine tailings in population which grow in nature potential [10]. Wen et al. (2001) planted 4 Datura seeds in different regions and do analysis of this 4 Datura habitats potential [11]. Gu et al. (2008) used RAPD to analyze genetic diversity of clethroides populations which grow in lead zinc tailings in the storing time of 10 years and 20 years in natural and contrast soil potential [12]. L. hexandra is a kind of important heavy metal chromium enrichment plant, so it is important to study its molecular enrichment mechanism. Therefore, this study used L. hexandra treated with heavy metal pollution in the laboratory as experimental materials, analyzed the genetic diversity of $L$. hexandra under different EDTA treatment of heavy metal chromium pollution through RAPD, and tried to explore the differentiation and evolution of L. hexandra population under long-term persistence of toxic heavy metals pollution from molecular level.

\section{Material and Methods}

\subsection{Materials}

\section{Plant material handling}

L. hexandra collected from Guilin city, China, and artificial cultivated in sunlight greenhouse. 400 mg chrome metal $\mathrm{Cr}^{3+}\left(\mathrm{CrCl}_{3}\right)$ to per $\mathrm{kg}$ were added to soil when L. hexandra planted. EDTA solution of $0 \mathrm{mmol} / \mathrm{L}, 2.5$ $\mathrm{mmol} / \mathrm{L}, 5 \mathrm{mmol} / \mathrm{L}$ and $10 \mathrm{mmol} / \mathrm{L}$ concentration were prepared to handle $L$. hexandra plant, 3 repeats for every kind of concentration gradient, joined the appropriate EDTA solutions to L. hexandra plant every other week, and added a total of 3 times.

Reagents and solutions

$2 \times$ CTAB extracting buffer (2\% CTAB, $1.4 \mathrm{~mol} / \mathrm{L} \mathrm{NaCl}$, and $20 \mathrm{mmol} / \mathrm{L}$ EDTA, and $100 \mathrm{mmol} / \mathrm{L} \mathrm{Tris-Cl}$, pH 8); phenol/chloroform/isoamyl alcohol (25:24:1), chloroform/isoamyl alcohol (24:1), $\beta$-mercaptoethanol; 3 mol/L NaAc, (pH 5.2) isopropyl alcohol; TE solution (10 mmol/L Tris-Cl, 1 mmol/LEDTA, pH 8); 75\% alcohol; alcohol; $1 \times$ TAE buffer (40 mmol/L Tris, and 20 mmol/L HAc, 1 mmol/L EDTA, pH 8.0), Taq DNA polymerase; agarose; Lambda DNA/EcoR I + Hind III Marker.

Instruments and equipments

General refrigerators; HVE-50 high pressure sterilization pot (Japan Hirayama), LEGEND MICRO17 high speed centrifuge (United States saimofei Fisher); trace moving liquid (Japan Nichipet EX); T1Thermocyler amplification apparatus (Germany BIOMETRA); DYY-12 Sanheng Multiple use Electrophoresis apparatus (Beijing Liuyi); DYCP-34A Electrophoresis tanks (Beijing Liuyi); MRS-1200048U scanner (Shanghai, Zhongjing technology); Furi FR-980 gel imager (Shanghai, Furi technology).

The primer sequences

The primer sequences used in this study are shown in Table 1.

\subsection{Experimental Methods}

\section{Extraction and purification for L. hexandra genomic DNA}


Table 1. RAPD random primer of Leersia hexandra Swartz

\begin{tabular}{|c|c|c|c|c|c|c|c|}
\hline NO & $\left(5^{\prime} \rightarrow 3^{\prime}\right)$ & NO & $\left(5^{\prime} \rightarrow 3^{\prime}\right)$ & NO & $\left(5^{\prime} \rightarrow 3^{\prime}\right)$ & NO & $\left(5^{\prime} \rightarrow 3^{\prime}\right)$ \\
\hline S41 & ACCGCGAAGG & S51 & AGCGCCATTG & S82 & GGCACTGAGG & S94 & GGATGAGACC \\
\hline S42 & GGACCCAACC & S52 & CACCGTATCC & S83 & GAGCССТCCA & S95 & ACTGGGACTC \\
\hline S43 & GTCGCCGTCA & S53 & GGGGTGACGA & S84 & AGCGTGTCTG & S96 & AGCGTCCTCC \\
\hline S44 & TCTGGTGAGG & S54 & СТTCСССАAG & S85 & CTGAGACGGA & S97 & ACGACCGACA \\
\hline S45 & TGAGCGGACA & S55 & CATCCGTGCT & S86 & GTGCCTAACC & S98 & GGCTCATGTG \\
\hline S46 & ACCTGAACGG & S56 & AGGGCGTAAG & S87 & GAACCTGCGG & S99 & GTCAGGGCAA \\
\hline S47 & TTGGCACGGG & S57 & TTTCCCACGG & S88 & TCACGTCCAC & $\mathrm{S} 60$ & ACCCGGTCAC \\
\hline S48 & GTGTGCCCCA & S58 & GAGAGCCAAC & S89 & CTGACGTCAC & S81 & CTACGGAGGA \\
\hline S49 & CTCTGGAGAC & S59 & CTGGGGACTT & S92 & CAGCTCACGA & S93 & CTCTCCGCCA \\
\hline
\end{tabular}

Applied an improved ctab method potential [13] [14], to extract total DNA from leaves of L. hexandra dried by silica gel, and used phenol/chloroform/isoamyl alcohol (25:24:1) to extract total DNA, anhydrous ethanol to purified total DNA, 0.8\% agarose gel electrophoresis to detect DNA extraction and effects.

Primers screening

Used L. hexandra genomic DNA extracted as DNA templates for RAPD random primers screening. Primers are used in this research process all synthesized by Shanghai bio-engineering technology services company limited. Random primers with clear RAPD amplification and stability response were screened for final primers of L. hexandra RAPD molecular markers.

$R A P D$ amplification reaction of L. hexandra

We used L. hexandra genomic DNA extracted as DNA templates for RAPD amplification reaction. Optimized reaction system: $25 \mu \mathrm{l}$ total volume, $18.5 \mu \mathrm{l}$ double distilled water, $2.5 \mu 110$ uffer liquid, $2 \mu 1 \mathrm{Mg}^{2+}$ concentration for $20 \mathrm{mmol} / \mathrm{L}, 0.5 \mu \mathrm{ldNTP}$ concentration for $200 \mu \mathrm{mol} / \mathrm{L}, 0.5 \mu \mathrm{l}$ primer concentration for $0.4 \mu \mathrm{mol} / \mathrm{L}, 1$ $\mu l$ template DNA originated from DNA extraction diluted 4 times with TE buffer liquid, $2 \mathrm{U} / 25 \mu \mathrm{T}$ Taq enzyme. Circulation system after optimized: for $5 \min 94^{\circ} \mathrm{C}$ predegeneration, then for 40 cycles, followed by 1 min $94^{\circ} \mathrm{C}$ predegeneration, $1 \mathrm{~min} 36^{\circ} \mathrm{C}$ annealing, $1 \mathrm{~min} 72^{\circ} \mathrm{C}$ stretch. Last, $7 \mathrm{~min} 72^{\circ} \mathrm{C}$ complete the extension potential [15]. All RAPD reactions were in T1 Thermocyler amplification a paratus (Germany BIOMETRA). Results of PCR amplified products detected by $0.8 \%$ agarose gel electrophoresis, and used Lambda DNA/Hind III + EcoR I Markers as molecular standard, and electrophoresis in $120 \mathrm{~V}$ constant-voltage for 40 min then do EB dyeing for 10 min, electrophoresis buffer of $1 \times$ TAE, observed by Furi FR-980 gel imaging device, and then taken pictures by the gel image analysis system.

\section{Results and Discussion}

\subsection{L. hexandra DNA Extraction Results}

Agarose gel electrophoresis results of $L$. hexandra leaves genomic DNA is shown in Figure 1. Test combined with common CTAB method for genomic DNA extraction, and extracted genomic DNA respectively for 12 samples, high quality DNA have great influence on stability and reliability experiment results. Seen from Figure 1 , the primary belt of $L$. hexandra genomic DNA is at about 21,226 bp. After agarose gel electrophoresis for DNA extracted from L. hexandra leaves, its band isn't very bright and clear but with much tail, which showed that process of DNA extraction degradated in severe, proteins and RNA degradation was not very thorough. To illustrate, extraction of DNA purity in this experiment was not high, but in little amount of DNA in RAPD experiment, generally, expansion just need $10 \mathrm{ng}$ to $50 \mathrm{ng}$ DNA, purity requirements were not very high. The RAPD results showed that the extraction genomic DNA from $L$. hexandra can be applied to RAPD reaction.

\subsection{L. hexandra RAPD Primers Screening Results}

Used L. hexandra genomic DNA as a template, for screening of the 46 UBC random primers, results showed 
that 29 UBC hadn't amplified products or obscured and couldn't tell, other 17 UBC random primers amplified a strip of clear and stable, that account for $36.9 \%$ of total primers. They varied approximately $200 \mathrm{bp}$ or $3000 \mathrm{bp}$ size, each primer amplification of fragments between changes in 1 - 7. Part L. hexandra leaves DNA RAPD primers screened results are as shown in Figure 2.

\subsection{L. hexandra RAPD Amplification Results}

Screened 46 random primers (see Table 1) preliminary, and used primers that can amplify stability and clear DNA bans as DNA amplification primers of $L$. hexandra polluted by chromium, and screened random primers S43, S51, S55 from tests results for RAPD reaction in this study. RAPD analysis was used for different samples of $L$. hexandra which under heavy metals chromium of $400 \mathrm{mg} / \mathrm{kg}$ concentration pollution and then added different concentration exogenous EDTA, sample RAPD results detected by agarose gel electrophoresis as shown in Figure 3, Figure 4 and Figure 5.

\subsection{RAPD Amplification Results of Primer S43}

Figure 3 shows the amplification results of S43 RAPD random primers of $L$. hexandra samples. EDTA concentration of the first sample was $0 \mathrm{mmol} / \mathrm{L}$ (contrast). EDTA concentration of the second and third sample was 2.5

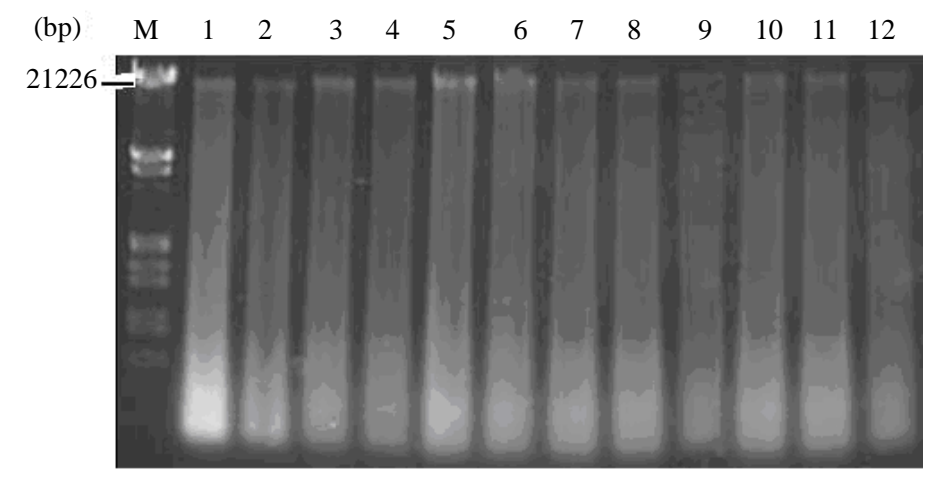

Figure 1. Leaves general DNA electrophoresis spectrums of $L$. hexandra, 1 - 3: EDTA 0 mmol/L; 4 - 6: EDTA 2.5 mmol/L; 7 - 9: EDTA $5.0 \mathrm{mmol} / \mathrm{L}$; 10 - 12: EDTA $10 \mathrm{mmol} / \mathrm{L}$. M is Lambda DNA/Hind III + EcoR I Markers.

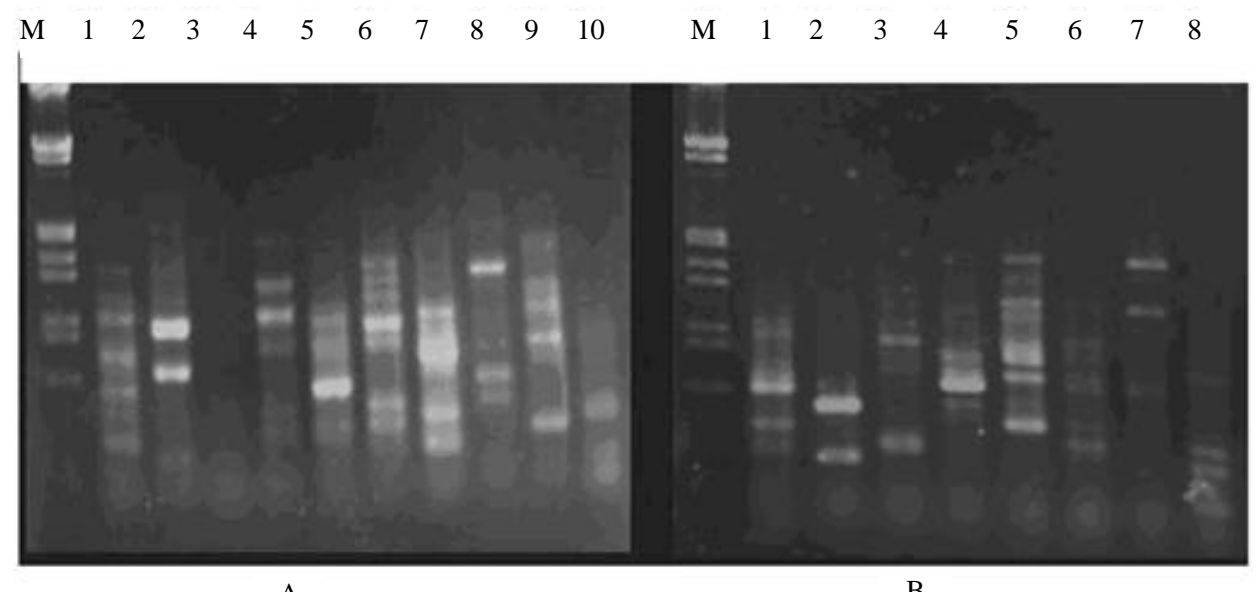

A

B

Figure 2. Filtered results of RAPD part primers in $L$. hexandra leaves DNA, A: Lane 1 - 10 Respectively Express Primer S51, S52, S57, S59, S60, S93, S94, S95, S96 and S97 amplification results; B: Lane 1 - 8 Respectively Express Primer S4, S9, S98, S99, S43, S44, S55 and S56 amplification results; M is Lambda DNA/Hind III + EcoR I Markers. 


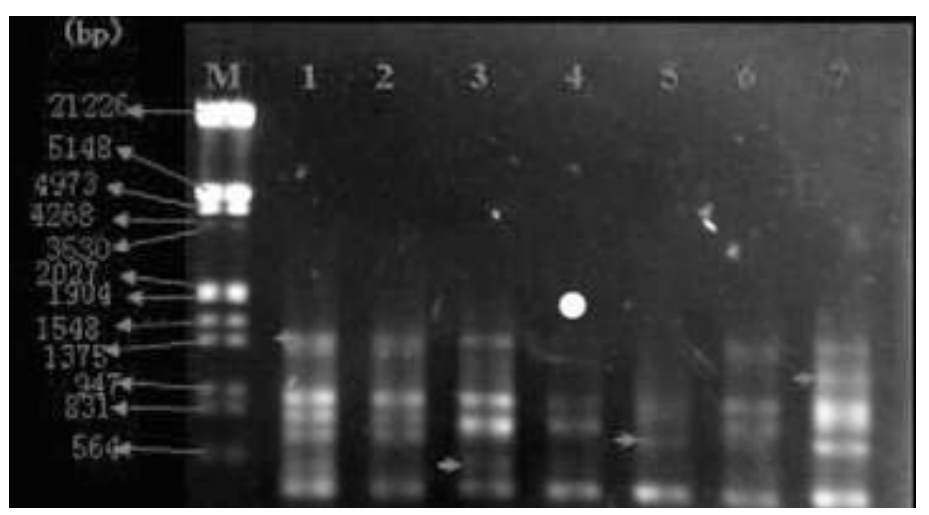

Figure 3. Amplification results in primer 43(GTCGCCGTCA) RAPD, 1: EDTA 0 mmol/L (Contrast); 2,3: EDTA $2.5 \mathrm{mmol} / \mathrm{L}$; 4,5: EDTA 5.0 $\mathrm{mmol} / \mathrm{L}$; 6,7: EDTA $10 \mathrm{mmol} / \mathrm{L}$; M is Lambda DNA/Hind III + EcoR I Markers.

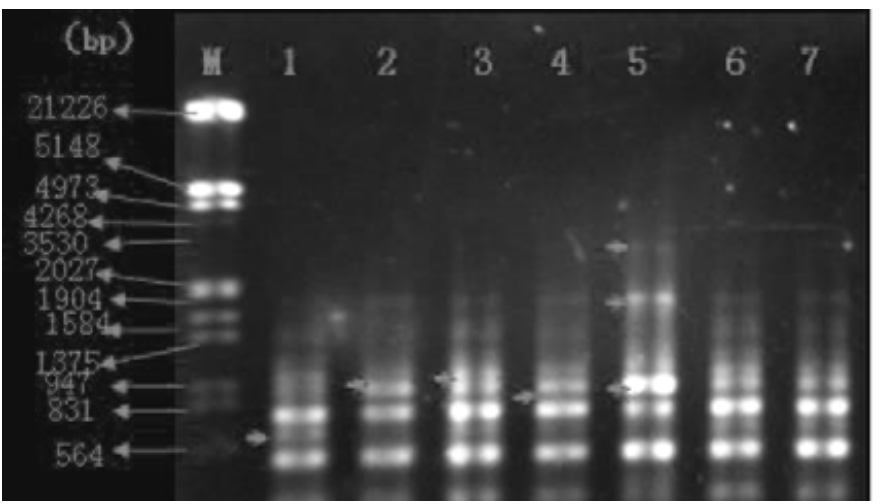

Figure 4. Amplification results in primer 51(GTCGCCGTCA) RAPD. The treatment of samples 1 - 7 is the same as Figure 3.

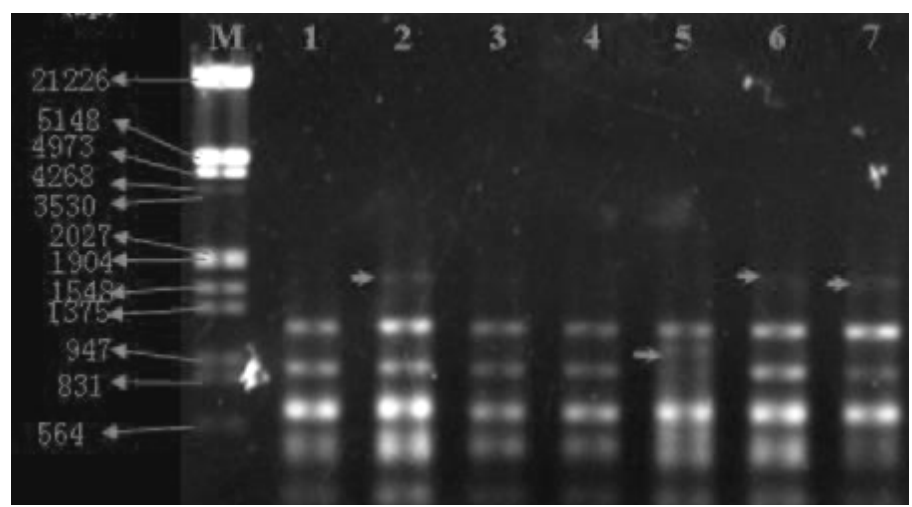

Figure 5. Amplification results in primer 55(GTCGCCGTCA)RAPD. The treatment of samples $1-7$ is the same as Figure 3 .

mmol/L and the third sample appeared DNA polymorphism at about 564 bp (as shown by the arrow in the 3rd sample). EDTA concentration of the fourth and fifth sample was $5 \mathrm{mmol} / \mathrm{L}$, and the fifth sample appeared DNA polymorphism at about 700 bp (as shown by the arrow in the 5th sample). EDTA concentration of the sixth and seventh sample was $10 \mathrm{mmol} / \mathrm{L}$, and the 7th appeared DNA polymorphism at about $1000 \mathrm{bp}$ (as shown by the arrow in the 7th sample).

EDTA concentration of the first was $0 \mathrm{mmol} / \mathrm{L}$ (contrast). Comparison between the second and third and the 
first samples, the third appeared DNA polymorphism at about 564 bp (as shown by the arrow in the 3rd sample). Comparison between the fourth and fifth sample and the first sample, both appeared strip absence at about 1375 bp (absence strip as shown by the arrow in the first sample), in addition, the fourth sample appeared strip absence at about 700 bp (absence strip as shown by the arrow in the first sample). Comparison between the sixth and seventh and the first sample, the sixth sample appeared strip absence at about 700 bp (as shown by the arrow in the first sample), and the seventh sample appeared DNA polymorphism at about 1000 bp (as shown by the arrow in the 7th sample).

$R A P D$ amplification results of primer $S 51$

Figure 4 shows the amplification results of S51 RAPD random primers of $L$. hexandra samples. EDTA concentration of the first was $0 \mathrm{mmol} / \mathrm{L}$ (contrast). EDTA concentration of the second and third sample was 2.5 $\mathrm{mmol} / \mathrm{L}$ and compared with each other, the third sample appeared DNA polymorphism at about 1000 bp (as shown by the arrow in the second sample). EDTA concentration of the fourth and fifth sample was $5 \mathrm{mmol} / \mathrm{L}$, and compared with each other, the fifth sample appeared DNA polymorphism at about 3530bp. EDTA concentration of the sixth and seventh sample was $10 \mathrm{mmol} / \mathrm{L}$, and compare result shown that both were almost no difference.

EDTA concentration of the first was $0 \mathrm{mmol} / \mathrm{L}$ (contrast). Comparison between the second and third and the first sample, both appeared DNA polymorphism at about 947 bp (as shown by the arrow in the 2nd and 3rd sample). Comparison between the fourth and fifth sample and the first sample, both appeared DNA polymorphism at about 947 bp (as shown by the arrow in the 4th and 5th sample), in addition, the 5th sample appeared DNA polymorphism at about 1904 bp and 3530 bp ( as shown by the arrow in the 5th sample), and both the samples appeared strip absence at about 700 bp (strip absence as shown by the arrow in the first sample). Compared to the sixth and seventh sample, the contrast showed no difference.

RAPD amplification results of primer 555

Figure 5 shows the amplification results of S55 RAPD random primers of L. hexandra samples. EDTA concentration of the first was $0 \mathrm{mmol} / \mathrm{L}$ (contrast). EDTA concentration of the second and third sample was 2.5 $\mathrm{mmol} / \mathrm{L}$ and compared with each other, the 2nd sample appeared DNA polymorphism at about 1548 bp (as shown by the arrow in the 2nd sample). EDTA concentration of the fourth and fifth sample was $5 \mathrm{mmol} / \mathrm{L}$, and the 5th sample appeared DNA polymorphism at about 947 bp (as shown by the arrow in the 5th sample). EDTA concentration of the sixth and seventh sample was $10 \mathrm{mmol} / \mathrm{L}$, and compared with each other, result shown that both were almost no difference.

EDTA concentration of the first was $0 \mathrm{mmol} / \mathrm{L}$ (contrast). Comparison between the second, the third and the first sample, the second sample appeared DNA polymorphism at about 1548 bp (as shown by the arrow in the 2nd sample). Comparison between the fourth, the fifth sample and the first sample, the fifth sample appeared DNA polymorphism at about 947 bp (as shown by the arrow in the 5th sample). Comparison between the sixth and seventh and the first sample, both samples appeared DNA polymorphism at about 1548 bp (as shown by the arrow in the 6th and 7th sample).

Study on the evolution of pollution can help to understand how plants adapt to the environment and evolve, to understand biological adaptation mechanism under pollution. Knowledge on the genetic diversity can be used in future breeding programs potential [16] [17]. Students concluded that DNA polymorphism detected by RAPD analysis in conjunction with other biochemical parameters could be a powerful eco-toxicological tool in biomonitoring arsenic pollution potential [18].

Heavy metal pollution is an important form of soil pollution, the past researches focused on heavy metal toxic effect and mechanism of plants, and study on migration, accumulation, distribution and other aspects on heavy metals in the plant's tissues, organs and ecological systems potential [19]. The accumulating ability of Leersia hexandra Swartz may be due to they live in electroplating waste water pollution in streams for a long time, in the process of adapting to this environment produced a variation, some genetic characteristics have changed, been the emergence of new forms of Chromium patience and Enrichment capacity also increased. And there are few studies on molecular ecology about plant under long-term effects of heavy metals. Through RAPD analysis of genetic diversity of $L$. hexandra under the heavy metals pollution, we can understand fundamental changes that is DNA level changes in the cells under tolerance in heavy metals pollution, so as to reform L. hexandra gene by using modern molecular techniques, to make greatly ability on enrichment and accumulation to heavy metals, so as to develop ability of restoring soil .

This study first screen primers of L. hexandra RAPD polymorphicing, and screen random primers S43 
(GTCGCCGTCA), S51 (AGCGCCATTG), S55 (CATCCGTGCT) from the 46 random primers to be random primers of L. hexandra RAPD molecular markers preliminary. And then used S43, S51, S55 as primers on the polymorphism of different samples for research. The combined use of both RAPD and ISSR markers for the genetic analysis of the cultivar varieties have been performed earlier potential [20] [21] (Gupta, et al., 2008, Lu, et al., 2009). Our study utilizes a total of 55 primers to disclose the genetic similarity between the selected varieties.

Compared EDTA concentration of $5 \mathrm{mM} / \mathrm{kg}, 10 \mathrm{mM} / \mathrm{kg}, 2.5 \mathrm{mM} / \mathrm{kg}$ with the control, the former expansion is larger than that of the latter. Different degrees of difference in comparison between different EDTA concentrations and control of treated RAPD results of L. hexandra, this shows that EDTA has certain effects during enrichment of $L$. hexandra to heavy metals. But perhaps, in a certain scope, it will be more favourable to $L$. hexandra accumulation of chromium metal when EDTA concentration increased. L. hexandra in the accumulation of chromium metal is also the process of chromium metal tolerance, and cause changes in gene eventually, to make it more resistant chromium metal against.

\section{Conclusion}

Different $L$. hexandra samples exhibited DNA polymorphism when using the random primer S43, S51 and S55 as the primers in the RAPD reaction. One specific DNA band about 1000 bp was found in the sample which was treated with $10 \mathrm{mmol} / \mathrm{L}$ concentration EDTA when used the S43 primer to RAPD. The obvious differences between different EDTA-treatment levels suggest that EDTA has not much effects on enrichment to heavy metals of $L$. hexandra, so we should do more work to research the $L$. hexandra accumulation of chromium mechanism when EDTA concentration increased.

\section{Acknowledgements}

This research was funded by Guangxi Nature Science of Foundation (2011GXNSFA018012), Key Discipline Physical Geography Established in Guilin University of Technology and Guangxi Key Laboratory of Hidden Metallic Ore Deposits Exploration Guilin University of Technology, Guilin, China.

\section{References}

[1] Zhang, X.H., Liu, J., Huang, H.T., Chen, J., Zhu, Y.N. and Wang, D.Q. (2007) Chromium Accumulation by the Hyperaccumulator Plant Leersia hexandra Swartz. Chemosphere, 67, 1138-1143. http://dx.doi.org/10.1016/j.chemosphere.2006.11.014

[2] Wang, T., Zhang, Q.B. and Ma, K.P. (2006) Treeline Dynamics in Relation to Climatic Variability in the Central Tianshan Mountains, Northwestern China. Global Ecology and Biogeography, 15, 406-415. http://dx.doi.org/10.1111/j.1466-822X.2006.00233.x

[3] Zhang, X.W. and Liu, B. (2010) Effect of Chromium on Crops Growth. Environmental Science, 23, 48-51.

[4] Hu, Y.Q. and Zhao, S.J. (2010) RAPD Technology and Its Application in Plant Research. Biotechnology Bulletin, 5, 74-77.

[5] Williams, J.G.K., Kubelik, A.R., Licak, J.A., et al. (1990) DNA Polymorphisms Amplified by Arbitrary Primers Are Useful as Genetic Marker. Nucleic Acids Research, 18, 6531-6535. http://dx.doi.org/10.1093/nar/18.22.6531

[6] Wen, C.H., Wang, Z.H. and Duan, C.Q. (1998) Pollution Resistant Differentiation and Evolution in Plants and the Application of Molecular Biology Technique. Ecological Science, 17, 19-24.

[7] Živković, B., Radović, J., Sokolović, D., Šiler, B., Banjanac, T. and Štrbanović, R. (2012) Assessment of Genetic Diversity among Alfalfa (Medicago sativa L.) Genotypes by Morphometry, Seed Storage Proteins and RAPD Analysis. Industrial Crops and Products, 40, 285-291. http://dx.doi.org/10.1016/j.indcrop.2012.03.027

[8] Bocianowski, J. and Seidler-Łożykowska, K. (2012) The Relationship between RAPD Markers and Quantitative Traits of Caraway (Carum carvi L.). Industrial Crops and Products, 36, 135-139. http://dx.doi.org/10.1016/j.indcrop.2011.08.019

[9] Cansaran-Duman, D., Atakol, O. and Aras, S. (2011) Assessment of Air Pollution Genotoxicity by RAPD in Evernia prunastri L. Ach. from around Iron-Steel Factory in Karabük, Turkey. Journal of Environmental Sciences, 23, 11711178. http://dx.doi.org/10.1016/S1001-0742(10)60505-0

[10] Li, J.M., Jin, Z.X. and Zhu, H.C. (2007) Heavy Metal Pollution Fern Population Genetic Differentiation Analysis of RAPD. Journal of Ecology, 26, 171-176. 
[11] Wen, C.H., Duan, C.Q., Xiu, C.X., et al. (2001) Heavy Metal Pollution of Differentiation of RAPD Analysis of Datura Stramonium L. Journal of Ecology, 21, 1238-1245.

[12] Gu, Q.P., Jin, Z.X. and Li, J.M. (2008) Under Heavy Metal Stress Clethroides Populations Genetic Diversity Analysis of RAPD. Jiangsu Agricultural Sciences, 2008, 54-58.

[13] Yu, Z.X., Ou, G.Z., Chen, Q.X., et al. (2010) Pitaya Total DNA Extraction Method Comparison Research. Agricultural Science Bulletin, 26, 300-303.

[14] Cheng, S.P., Shi, J., Shi, G.A., et al. (2010) Pistacia chinensis Leaf Genomic DNA Extraction Methods. Journal of Henan University of Science and Technology, 31, 71-73.

[15] Wang, J.J., Wu, S.L., Zhang, F.C., et al. (2010) Grape Genome DNA Extraction and RAPD Reaction System Optimization. Agricultural Sciences of Xinjiang, 47, 1066-1070.

[16] Lin, G.M., Sui, F.F., Lin, N., et al. (2010) Wilfordii Leaf DNA Extraction and RAPD Reaction System. Chinese Agricultural Science Bulletin, 26, 40-43.

[17] Singh, S., Panda, M.K. and Nayak, S. (2012) Evaluation of Genetic Diversity in Turmeric (Curcuma longa L.) Using RAPD and ISSR Markers. Industrial Crops and Products, 37, 284-291.

[18] Ahmad, M.A., Gaur, R. and Gupta, M. (2012) Comparative Biochemical and RAPD Analysis in Two Varieties of Rice (Oryza sativa) under Arsenic Stress by Using Various Biomarkers. Journal of Hazardous Materials, 217-218, 141-148. http://dx.doi.org/10.1016/j.jhazmat.2012.03.005

[19] Tang, Y., Wang, P.P. and Zhang, N. (2006) Research in Heavy Metal Toxicity Mechanism in Plant. Journal of Shengyang Agricutural University, 37, 551-555.

[20] Tao, J.X., Zhang, X.H., Luo, H., et al. (2010) Leersia hexandra Swartz for Electroplating Sludge Contaminated Soil Chromium Copper Nickel Uptake and Accumulation. Journal of Guilin University of Technology, 30, 144-147.

[21] Gupta, S., Srivastava, M., Mishra, G.P., Naik, P.K., Chauhan, R.S., Tiwari, S.K., Kumar, M. and Singh, R. (2008) Analogy of ISSR and RAPD Markers for Comparative Analysis of Genetic Diversity among Different Jatropha curcas Genotypes. African Journal of Biotechnology, 7, 4230-4243. 
Scientific Research Publishing (SCIRP) is one of the largest Open Access journal publishers. It is currently publishing more than 200 open access, online, peer-reviewed journals covering a wide range of academic disciplines. SCIRP serves the worldwide academic communities and contributes to the progress and application of science with its publication.

Other selected journals from SCIRP are listed as below. Submit your manuscript to us via either submit@scirp.org or Online Submission Portal.
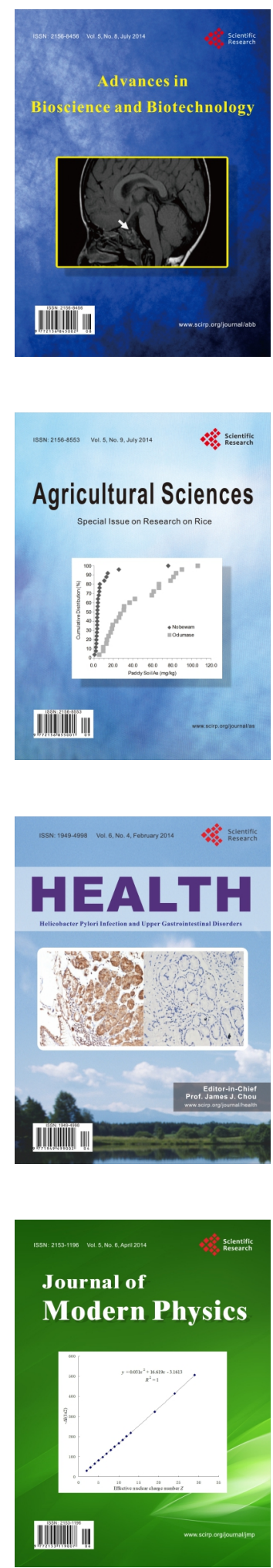
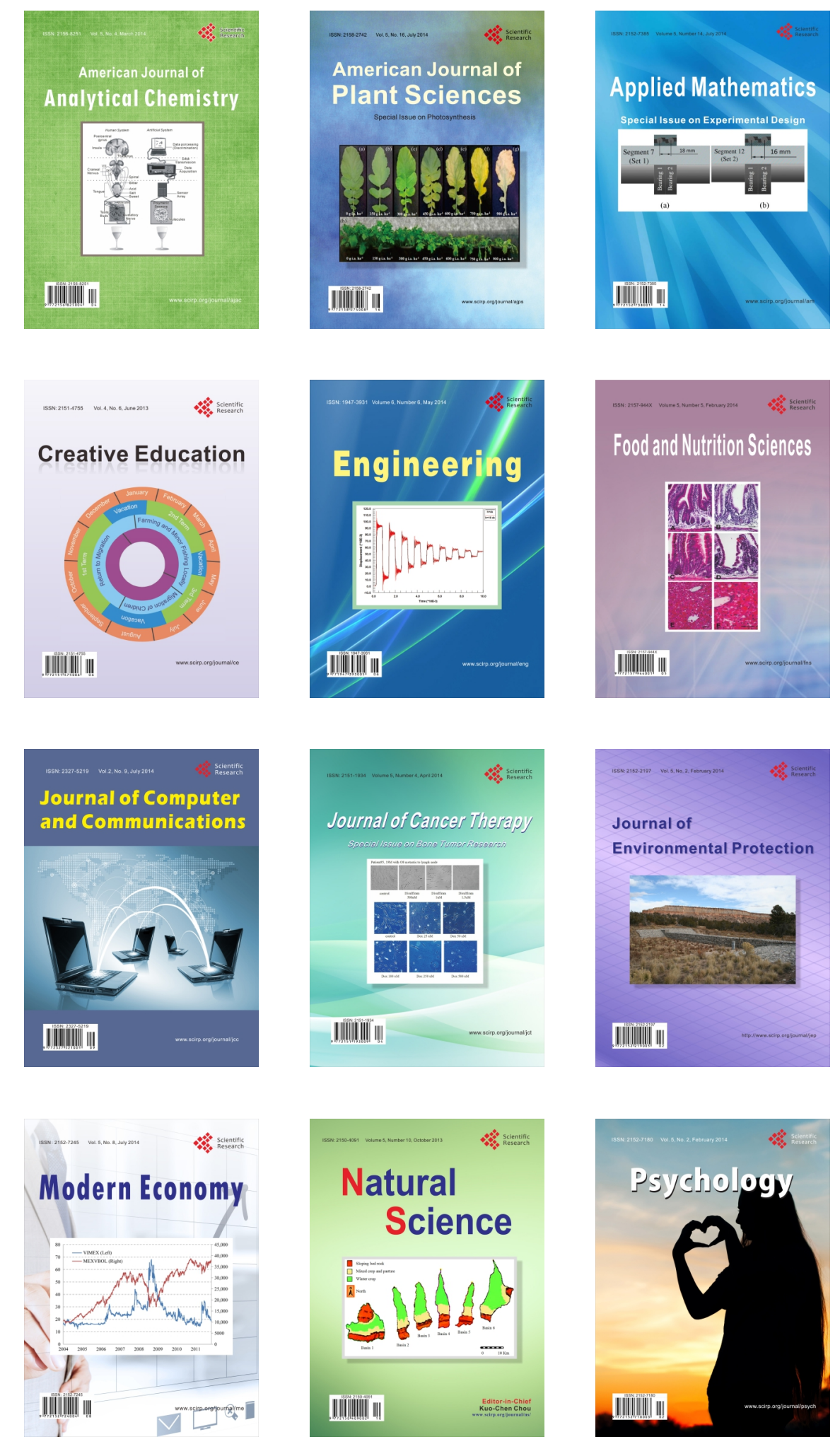